\title{
Misnay József hmtk. ezredes
}

\section{Magyar hadmérnök, akiről fizikai hatást neveztek el}

$\mathrm{M}$ isnay József 1904. augusztus 13-án született Budafokon. Iskolai tanulmányait is Budafokon folytatta, és 1922-ben, jeles eredménnyel ott is érettségizett. Édesapja Misnay Jenő csendőr százados, édesanyja Keszner Mária Anna. Középiskoláinak befejezése után a Ludovika Akadémián folytatta tanulmányait. Pályája kezdetén különböző tanintézetekben folytatott oktatói tevékenységet (pl.: részt vett a tisztsarjadék-oktatásban és -kiképzésben, altiszti képzésben és oktatott a magyar királyi Honvéd Bolyai János Műszaki Akadémián és az magyar királyi Rendőrújonc Iskolán is). 1938-ban diplomázott a Magyar Királyi József Nádor Műszaki és Gazdaságtudományi Egyetem mérnöki tagozatán. 1938-tól 1944-ig dolgozott a Magyar Királyi Honvéd Haditechnikai Intézetben. 1942-re az összes hadiműszaki törzskari (hmtk.) vizsgát kiváló eredménnyel és évfolyamelsőként tette le. Volt olyan kortársa, akinek ez a vizsga csak elégségesre sikerült, amelynek következtében elbocsájtották a Haditechnikai Intézet állományából és más katonai alakulatnál kellett folytatnia pályafutását.

Nem tudni pontosan, mikortól kezdve foglalkozott egy új típusú, kumulatív hatáson alapuló akna kifejlesztésén, de 1942-ből fennmaradt egy hadiműszaki törzskari előadása az „üreges töltetekről”, és ezzel megalapozta elsőségét egy addig ismeretlen területen. A jelenség lényege, hogyha az üreges töltetbe elég nagy tömegű és formájú fémet helyezünk el, akkor az irányított robbanás után egy testet alkot, és nem szakadozik szét, mint a kumulatív sugár a fókusztávolság után. Ez a robbantással formált lövedék, angol néven explosively formed projectile (EFP). Ha a méretezés és a robbantással történő formázás jól sikerül, a lövedék, relatív nagy távolságon jelentős páncélvastagsá-

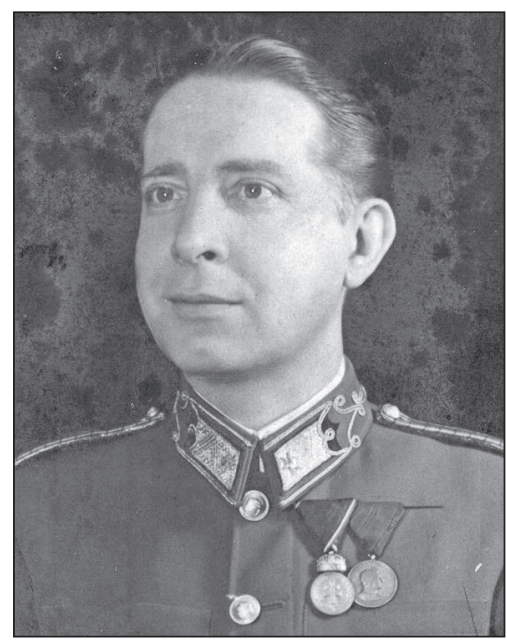

gon képes áthatolni. A kísérletek eredményeképpen rendszeresítésre került a $43 \mathrm{M}$, majd a $44 \mathrm{M}$ LŐTAK (Iövő tányérakna) és a $43 \mathrm{M}$ magyar kumulatív harckocsi elleni akna. A 43M LÖTAK volt a világon az első akna, amelyet az oldalpáncél átrobbantására alkalmaztak. Elképzelhető, hogy

1. ábra. Misnay József hmtk. örnagy az aknákat az Árpád-vonal műszaki zárainál is használták, de a budai vár védelmében és nyugat-magyarországi települések védelme során is biztosan szerepet kapott.

$\mathrm{Az}$ eredményekre felfigyelt dr. Hubert Schardin német professzor is, aki szintén foglalkozott a hatás vizsgálatával és a jelenség elméletével. Schardin 1944 nyarán, Budapesten ismerkedett meg részletesebben Misnay gyakorlati eredményeivel, áttanulmányozta a kísérletek, a vizsgálatok és az eredmények dokumentációját. Schardin a Gestapo budapesti épületébe rendeltette be Misnayt. A látogatás mély nyomokat hagyott a korábban sem németbarát hadmérnökben. Eredményeinek a tudományos közélet előtti bemutatására Misnaynak soha nem volt lehetősége. A jelenség leírását Schardin a háború után több helyen is

\section{2. ábra. Misnay József elismerő oklevele Horthy Miklós} kormányzótól
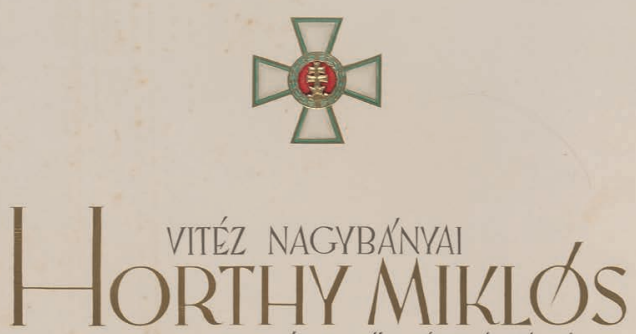

MAGYARORSZÁG FÖMÉLTOSÁGÚ KORMANYZOJA
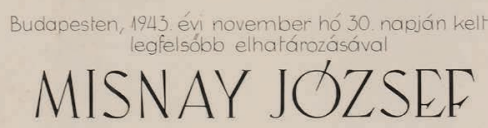

$\mathrm{m}$. kir hm. th alezredes úrnak,

a hadimúszakik torzskari szolgálat terén kifejtett
kiválóoneredményes és hasznos teljesitményeiér

A MAGYAR ÉRDEMREND

LOVAGKERESZTJÉT ADOMÁNYOZNI MELTOZTATOTT.

MIROL EZT AZ OKLEVELET KIADOM.
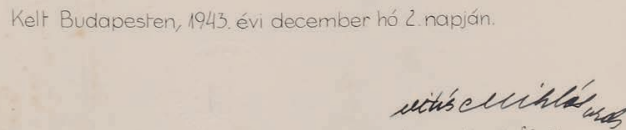

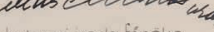
- akatonai iroda fónoke

MH Logisztikai Központ, mb. technológiai igazgató, adjunktus, Nemzeti Közszolgálati Egyetem, Katonai Műszaki Doktori Iskola. HDF Logistic Center, technological director, lecturer, National University of Public Service, Doctoral School of Military Engineering, e-mail: Hajdu.Ferenc@hm.gov.hu ORCID: 0000-0003-0449-7678 


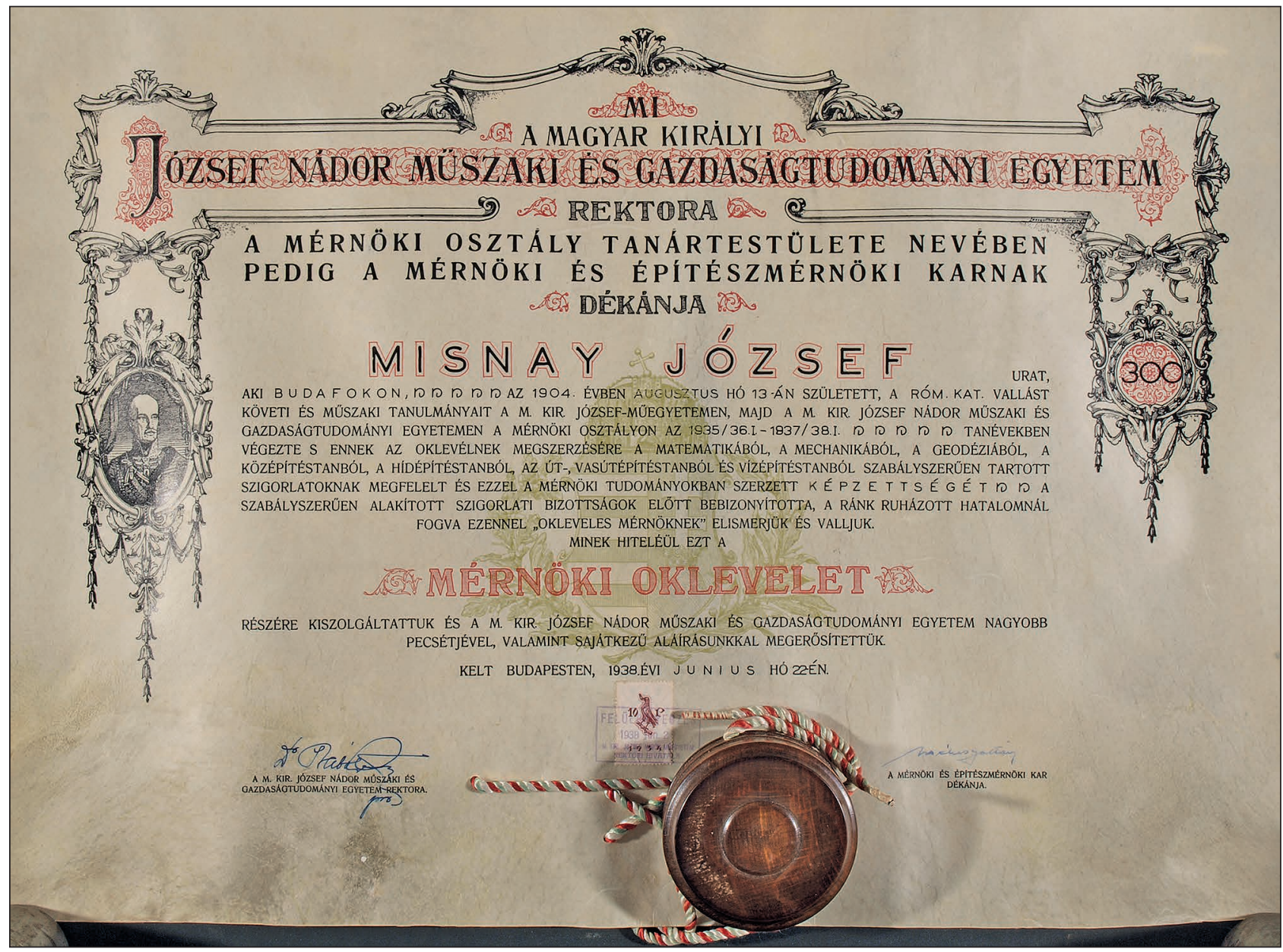

\section{3. ábra. Misnay József 1938-ban kiállított mérnöki oklevele}

publikálta, például a VDI. Zeitschrift 1956. november 21-én megjelent, 33. számban, ahol azt írta, hogy „A MisnaySchardin effektusként ismert folyamatot Misnay ezredes a gyakorlatban a II. világháború alatt kipróbálta és a Haditechnikai Intézetben elméletileg és méréstechnikailag pontosabban meg is vizsgálták". E publikáció egyik érdekessége, hogy Schardin vajon honnan tudta, hogy Misnayt, egy rendkívül zárt intézet őrnagyát a vasfüggöny mögött, időközben ezredesnek léptették elő. Eredményeik elismeréseként, a jelenségről az angolszász szakirodalom Misnay-Schardin effektus néven emlékezik meg. Kísérletei során sikerült a páncélokat nagyobb távolságról átrobbantani.

Visszaemlékezései szerint 1945. január 7-én, kémkedés gyanúiával a németek letartóztatták és halálra ítélték. Január 11-től cseh területen, majd február 14-től Bajorországban tartották fogva. Egy jelentésben az szerepel, hogy május 4-én az amerikai 14. hadosztály egy járőre, F. H. David hadnagy szabadította ki. A történet bizonyosan csak az igazoló bizottságnak szolgáló mese volt, mert adatok bizonyítják, hogy 1945. március 26-án még Győrött tartott előadást német és magyar utászok számára a LŐTAK telepítéséről és használatáról. A félelem olyan erős volt benne, hogy a '60-as évek elején gyermek tanítványának is az igazoló bizottság számára kitalált mesét adta elő.

1945. október 10-én szolgálatra jelentkezett az új Magyar Honvédségbe, és december 10-i hatállyal fel is vették. 1947. október 1-én nyugállományba helyezték, de egy év múlva, 1948 októberében reaktiválták, a Haditechnikai In- tézet állományába került hmtk. alezredesi rendfokozattal. Folytatta a LOTAK fejlesztését, de az eredményekről nem maradt fenn adat. Kísérleteket végzett még az oldal elleni akna nagyobb távolságból történő használatára, amelyet - visszaemlékezése szerint - trotilágyúnak nevezett el. A LŐTAK és az azt követő fegyvereink már jobb páncélátütő tulajdonsággal rendelkeztek, mint a korábbi kumulatív hatáson alapuló fegyverek. A megfelelően méretezett és formázott béléstest a robbanás után nem válik szét, hanem nagy távolságban is egy tömeget alkot, és hatol át a járművek pácélzatán. Később foglalkozott még a kumulatív puskagránát fejlesztésével is.

Eredményeinek köszönhetően feljebb emelkedett a ranglétrán, ezredessé léptették elő. 1950 után a régi tisztek iránti bizalmatlansági hullám őt is elérte. A trotilágyús kísérletei miatt - amelyek során több száz méterről akart harckocsikat megsemmisíteni -, bolondnak bélyegezték. Az akkori bolondnak tartott gondolatok ma már mindennapos fenyegetettséget jelentenek iraki és afgán területeken.

1950 második felében letartóztatták és kitelepítették Tiszafüredre. Az ÁVH hetente többször is "meglátogatta”, ezek az ellenőrzések kikezdték az idegeit. Felesége, Lipcsey llona, gyermekgondozóként dolgozott. Misnay József, élete utolsó éveiben gyerekeket korrepetált matematikából és fizikából. 1968. november 16-án hunyt el Tiszafüreden, ahol máig ismeretlen helyen nyugszik.

Misnay József ezredes örökre beírta nevét a hadtudomány aranykönyvébe, ám a kor, amelyben élt, és amelyben maradandót alkotott, majdnem feledésre ítélte. 